\title{
Interactive Animation Design of Hijaiyah Letters in Early Age Children at Al-Hidayah Kindergarten Bekasi
}

\author{
Rika Darmawati \\ STMIK Nusa Mandiri \\ Jl. Kramat Raya No. 18 \\ Jakarta Pusat 10450 \\ rikadarmawati21@gmail.com
}

\author{
Henny Destiana \\ Universitas Bina Sarana Informatika \\ JL. Kamal Raya No. 18, Ringroad Barat \\ Cengkareng, Jakarta Barat \\ Henny.hnd@bsi.ac.id
}

\begin{abstract}
Education about religious sciences, especially hijaiyah letters is very important as a provision to be understood by humans as the basis of their lives to face life in the future. The difficulties experienced are quite reasonable, because the Al-Qur'an uses Arabic. Learning with the Koran system is usually done in a relatively long time even sometimes for years. This is not effective and efficient in teaching and learning activities. So with the presence of a new learning media to utilize computer technology, it is expected to be developed into interesting learning for kindergarten children. Therefore, the authors make interactive animated hijiayah letter recognition so that with interactive application of the introduction to hijaiyah letters for early childhood at Al-Hidayah Kindergarten Bekasi is very helpful in teaching and learning process to be more fun and effective so students are no longer bored in learning and attracted the interest of students to a better understanding of how to read good and correct hijaiyah letters. With the Waterfall method, step by step through must wait for the completion of the previous stage and run sequentially. This model proposes an approach to systematic and sequential software development that starts from the level of system progress in all analysis, design, code, testing and maintenance. This model covers the following activities: Information system modeling and engineering, needs analysis, design, coding, testing and maintenance As well as helping teachers to innovate in the learning process because with this interactive animation application the instructors become easier to deliver material about the prayer movements to students.
\end{abstract}

Keyword - Interactive Animation, Introduction to Hijaiyah Letters, Early Age

\section{INTRODUCTION}

Education about religious sciences, especially hijaiyah letters is very important as a provision to be understood by humans as the basis of their lives to face life in the future. Difficulties experienced are quite reasonable, because the Qur'an uses Arabic. Teaching reading hijaiyah letters in RA (Raudatul Athfal, same as Kindergarten level) is usually done through the Koran system to learn to read the Koran with teachers in RA AL- Hidayah. Learning with the Koran system is usually done in a relatively long time even sometimes for years. This is not effective and efficient in teaching and learning activities.

media. One of the uses of computers in learning activities is to become a learning media. So that the introduction of hijaiyah letters through interactive learning is one of the learning media that can be poured into a CD and can be developed into interesting learning for kindergarten children. So with the presence of a new learning media to utilize computer technology, it is expected to be developed into interesting learning for kindergarten children.

\section{THEORETICAL REVIEW}

\section{A. Library Studies}

There are several studies regarding this research, for example,

\section{[1] According to [2]:}

"In the era of development, especially in the field of technology, human needs a media that can be used to solve problems quickly. One of them is how to introduce Hijaiyah letters quickly and attractively to TPA children who are still toddlers. So far the students at TPA still use iqro books as learning media for hijaiyah letters. This method includes less favored by the santri. Using a computer is one 
of the right ways to solve the problem. Writers who have tried to apply hijaiyah letter learning through a computer and this method was successfully liked by the santri. So the author wants to make an educational media that is interesting for santri so they can quickly read the Koran. "The shortcomings in the system are as follows:

a. So far, the software can only be used by one admin.

b. Because this software has never been there before, it takes training for admin to use it.

c. Based on the results of testing this software still has some errors in the program.

The advantages of this system are:

a. Make an educational media that is interesting for santri so they can quickly read the Al-Quran

b. One of the right ways to solve problems

c. This software is made based on the desktop so that it is more user-friendly so users can understand how to use this software easily

On the other hand, according to [3] suggests that: "Learning media that rely solely on writing instruments such as books, paper, pencils, or pens in the teachinglearning process lead to inaccurate communication between parents or teachers and children or students. Hijiyah letters are letters contained in AL-Quran and are written using Arabic letters. In this case, the learning media must be more creative in applying learning methods to increase the interest in learning at the age of the toddler, especially reading learning for children under five to provide knowledge before continuing to further education. Based on the problems studied, namely increasing the ability to read the hijaiyah letters through the adobe flash CS6 professional application. This interactive application is expected to benefit our children. Learning media that are presented are of course learning while playing with the aim of fostering interest in learning and introducing information technology to toddlers.

The shortcomings in the system are as follows:

a. So far the software can only be used by one admin

b. Based on the results of testing this software still has some errors in the program.

c. Based on the results of testing this software still has some errors in the program.

The advantages of this system are:

a. Animated assisted learning is more interesting, more interactive

b. the amount of teaching time can be reduced, the quality of children's learning can be improved and the teaching and learning process can be done anytime and anywhere. c. This software is made based on the desktop so that it is more user-friendly so users can understand how to use this software easily.

\section{RESEARCH METHODOLOGY}

The research method is a series of activities to obtain data or information from the object under study.

according to [4]This model proposes an approach to systematic and sequential software development that starts from the level of system progress in all analysis, design, code, testing, and maintenance. This model covers the following activities: Information system modeling and engineering needs analysis, design, coding, testing, and maintenance.

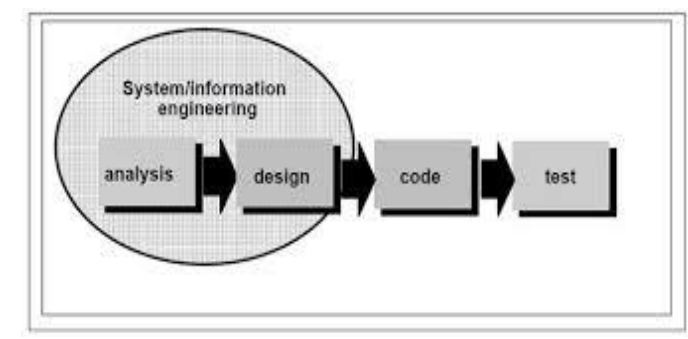

Figure 1. Illustration of the Waterfall Method

The explanation of the waterfall stages of the model is as follows:

a. Software Requirements Analysis

Analyze and collect data to be used as a reference both from books and articles and dictates about software needed in software design and to be realized.

b. Design

Creating a system design that will be created, from the initial design to the end so as to make it easier to realize the software that will be made

c. Code Generation

At this stage, Action Script is used as a programming language in Adobe Flash CS6 to execute commands from elements previously created multimedia.

d. Testing

At this stage, do the testing system software that has been created, looking for bugs or system errors that occur, so as to reduce errors that occur in the system.

e. Support

At this stage, the author makes the application using Flash CS6 software. 


\section{RESULTS AND DISCUSSION}

\section{B. Software Requirements Analysis}

Analysis of the needs of the author on the software will produce software requirements specifications that will be made to determine a need for making interactive animation applications learning letters hijaiyah.

\section{User Needs}

User requirements in making the interactive hijaiyah letter application program as follows:

a. Users need hijaiyah letters to learn to read well.

b. Users need a sound to listen to the sound of the letters hijaiyah

c. Users need more interesting learning media.

d. The user can input the answer to the specified question

e. The user needs a value output.

2. System requirements

according to [5] At the stage of analyzing system requirements, the author identifies several devices that must be used to create and run a software application, here are the specifications that the author uses:

a. hardware specifications Hardware or hardware is a device that can help the performance of the operating system, which is a vital part of the software.

b. software specifications. according to [6]software or software that the author uses in designing interactive animations for introducing hijaiyah letters as follows:

1) Adobe Flash CS6

2) Adobe Photoshop CS

3) Windows 7 operating system

\section{B. Design}

Before the animation of hijaiyah letter learning is implemented in the form of a computer program or application, it needs to be designed through a concept desired by the author through the design of storyboards, user interfaces, and state transition diagrams. Where the design stage of this design aims to meet user needs and provide an overview of the program or application that you want to make.

1. Designing a StoryBoard

The storyboard design contains a discussion of the storyline of interactive animation which will be explained about the displays in the program.

a. Storyboard of the opening scene

An overview of the storyboard of the opening scene is explained in the following table:
Table.1

Storyboard of the opening scene

\begin{tabular}{|c|c|}
\hline VISUAL & SKETSA \\
\hline $\begin{array}{c}\text { Pada scene menu } \\
\text { utama terdapat } \\
\text { beberapa tombol, } \\
\text { mulai dari tombol } \\
\text { pengenalan huruf } \\
\text { hijaiyah, tombol } \\
\text { pengenalan harakat, } \\
\text { tombol bermain. } \\
\text { Selain dari tombol } \\
\text { tersebut terdapat } \\
\text { gambar karakter. Dan } \\
\text { teks itu bertuliskan } \\
\text { belajar huruf hijaiyah. }\end{array}$ & $\begin{array}{c}\text { Teluar } \\
\text { pengenalan huruf } \\
\text { hijaiyah }\end{array}$ \\
\cline { 2 - 2 } & $\begin{array}{c}\text { Tombol } \\
\text { pengenalan } \\
\text { harakat }\end{array}$ \\
\hline
\end{tabular}

b. Storyboard Main Menu

The following is an overview of the Main Storyboard Menu as described in the table below:

Table 2.

Storyboard Main Menu

\begin{tabular}{|l|c|}
\hline \multicolumn{1}{|c|}{ VISUAL } & SKETSA \\
\hline $\begin{array}{l}\text { In the main scene menu, } \\
\text { there are a number of } \\
\text { buttons, starting from the } \\
\text { hijaiyah letter recognition } \\
\text { button, charity recognition } \\
\text { button, play button. Apart } \\
\text { from the button, there is a } \\
\text { character image. And the } \\
\text { text reads learning letters } \\
\text { hijaiyah. }\end{array}$ \\
$\begin{array}{l}\text { Bigar } \\
\text { of hijaiyah letters }\end{array}$ \\
\hline
\end{tabular}

c. Storyboard Introduction to Hijaiyah Letters The following is an overview of the Storyboard of hijaiyah letter recognition as described in the table below: 
Table 3.

Storyboard Introduction to hijaiyah letters

\begin{tabular}{|l|c|}
\hline \multicolumn{1}{|c|}{ VISUAL } & SKETCH \\
\hline $\begin{array}{l}\text { In the hijaiyah } \\
\text { letter recognition } \\
\text { scene, there are } \\
\text { gif, text, back }\end{array}$ & \\
button, and \\
material to be \\
learned, the \\
material is in the \\
form of hijaiyah \\
letters, where the \\
letter has a sound \\
or sound if one of \\
the hijaiyah letters \\
is clicked.
\end{tabular}

a. Storyboard of Introduction to Harakat

The following is an overview of the Harakat Recognition Storyboard as described in the table below:

Table 4.

Storyboard of Introduction to Harakat

\begin{tabular}{|l|c|}
\hline \multicolumn{1}{|c|}{ VISUAL } & SKETSA \\
\hline $\begin{array}{l}\text { In the scene, the awarding } \\
\text { of the title is a number of } \\
\text { buttons, starting from the } \\
\text { fathah button, the keypad, } \\
\text { the main button, and the } \\
\text { button back to the } \\
\text { previous menu. Apart } \\
\text { from the button, there is a } \\
\text { character image and the } \\
\text { text is in the form of an } \\
\text { introduction to charity. }\end{array}$ & $\begin{array}{c}\text { Picture } \\
\text { character }\end{array}$ \\
\cline { 2 - 2 } & $\begin{array}{l}\text { Button } \\
\text { fathah }\end{array}$ \\
\cline { 2 - 2 } & $\begin{array}{l}\text { button } \\
\text { kasroh }\end{array}$ \\
\hline & $\begin{array}{l}\text { Button } \\
\text { domah }\end{array}$ \\
\hline
\end{tabular}

e. Fathah Storyboard Material

The following is an overview of the Storyboard Material Fathah meter as described in the table below:
Table 5.

Fathah Storyboard Material

\begin{tabular}{|l|l|}
\hline \multicolumn{1}{|c|}{ VISUAL } & \multicolumn{1}{|c|}{ SKETCH } \\
\hline $\begin{array}{l}\text { In the } \\
\text { material } \\
\text { scene that has } \\
\text { fathah } \\
\text { society, there } \\
\text { is material } \\
\text { that wants to } \\
\text { be studied, } \\
\text { the material is } \\
\text { in the form of } \\
\text { hijaiyah } \\
\text { letters that } \\
\text { use fathah } \\
\text { and where the } \\
\text { letter hijaiyah } \\
\text { uses the } \\
\text { fathah there is } \\
\text { a sound or } \\
\text { sound if one } \\
\text { of the letters }\end{array}$ \\
\hline
\end{tabular}

f. Material Storyboard

The following is an overview of the Cashboard

Storyboard Material as described in the table below:

Table 6

Storyboard Material kasroh

\begin{tabular}{|l|l|}
\hline \multicolumn{1}{|c|}{ VISUAL } & SKETCH \\
\hline $\begin{array}{l}\text { In the material scene } \\
\text { that has this kasroh } \\
\text { community, there is } \\
\text { material that wants to } \\
\text { be studied, the } \\
\text { material is in the form } \\
\text { of hijaiyah letters that } \\
\text { use the hajj kasroh } \\
\text { and where the } \\
\text { hijaiyah letters that } \\
\text { use the chord are the } \\
\text { sound or sound if one } \\
\text { of the hijaiyah letters } \\
\text { is clicked. And the } \\
\text { back button is useful } \\
\text { for returning to the } \\
\text { introduction page }\end{array}$ & $\begin{array}{l}\text { Hijaiyah } \\
\text { material which } \\
\text { is berharakat } \\
\text { kasroh }\end{array}$ \\
\hline
\end{tabular}

g. Domah Material Storyboard

The following is an overview of the Domah Material Storyboard as described in the table below: 
Table 7.

Domah Material Storyboard

h.

\begin{tabular}{|l|l|}
\hline \multicolumn{1}{|c|}{ VISUAL } & SKETCH \\
\hline $\begin{array}{l}\text { In the material } \\
\text { scene that is } \\
\text { socially dominant, } \\
\text { there is material that } \\
\text { wants to be studied, } \\
\text { the material is in the } \\
\text { form of hijaiyah } \\
\text { letters that use } \\
\text { domah and where } \\
\text { hijaiyah letters that } \\
\text { use the domah are } \\
\text { there a sound or } \\
\text { sound if one of the } \\
\text { hijaiyah letters is } \\
\text { clicked. And the } \\
\text { back button is the } \\
\text { point to go back to } \\
\text { the Alms } \\
\text { Recognition page } \\
\text { harakat }\end{array}$ \\
\hline
\end{tabular}

Storyboard

The following is an overview of the Play Storyboard as described in the table below:

Table 8

Play Storyboard

\begin{tabular}{|l|c|}
\hline \multicolumn{1}{|c|}{ VISUAL } & SKETSA \\
\hline $\begin{array}{l}\text { In this playing scene } \\
\text { by guessing the letters } \\
\text { hijaiyah. The way to } \\
\text { play is guessing one } \\
\text { of the hijaiyah letters } \\
\text { by listening to the } \\
\text { voice commands and } \\
\text { after listening to the } \\
\text { user can immediately } \\
\text { guess the hijaiyah } \\
\text { letter by clicking on } \\
\text { one of the hijaiyah } \\
\text { letters. The exit } \\
\text { button is for returning } \\
\text { to the learning menu } \\
\text { view. }\end{array}$ \\
\begin{tabular}{|l} 
\\
\end{tabular} \\
\hline
\end{tabular}

i. Value Storyboard

The following is an overview of the Storyboard Value as explained in the table below:
Table 9.

Value Storyboard

\begin{tabular}{|l|l|}
\hline \multicolumn{1}{|c|}{ VISUAL } & \multicolumn{1}{|c|}{ SKETSA } \\
\hline $\begin{array}{l}\text { In this value scene } \\
\text { there will be a display } \\
\text { of values obtained } \\
\text { when playing, there are } \\
\text { two buttons, the play } \\
\text { button again and the } \\
\text { button is finished. If } \\
\text { chosen to play again, it } \\
\text { will return to the play } \\
\text { menu, if selected is } \\
\text { finished, it will return } \\
\text { to the main menu. }\end{array}$ & \multicolumn{2}{|l}{ Play } \\
\hline
\end{tabular}

\section{C.User Interface}

The user interface is an illustration of the user interface design and interactive information on the introduction of hijaiyah letters. in this section there are several pages such as:

\section{Welcome Home Page}

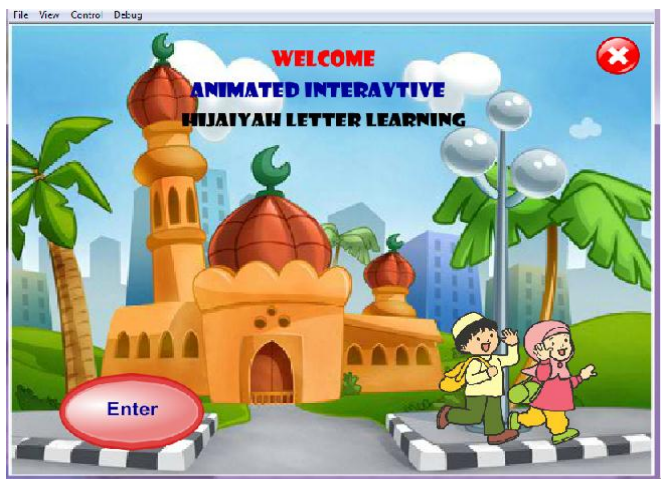

Picture 1.

\section{Home Page welcome}

\section{Main Menu Page}

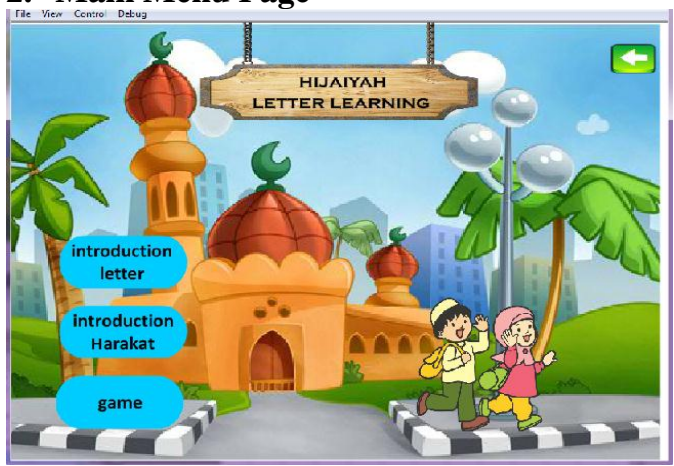

Picture 2. Main Menu Page 


\section{Introduction Letter Page Hijiayah}

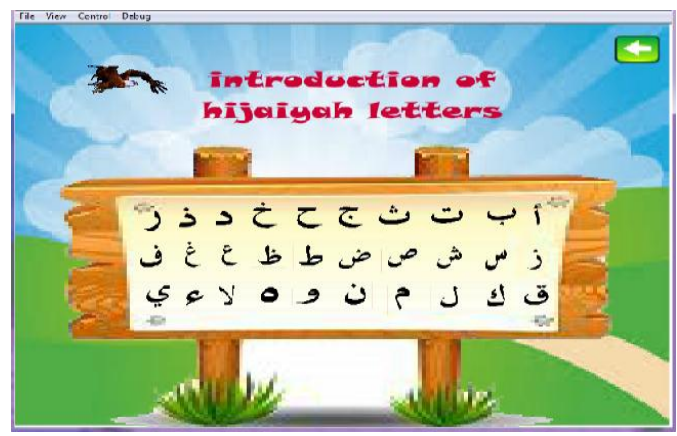

Picture 3. Introduction Letter Page Hijaiyah

\section{Halaman Materi Fathah}

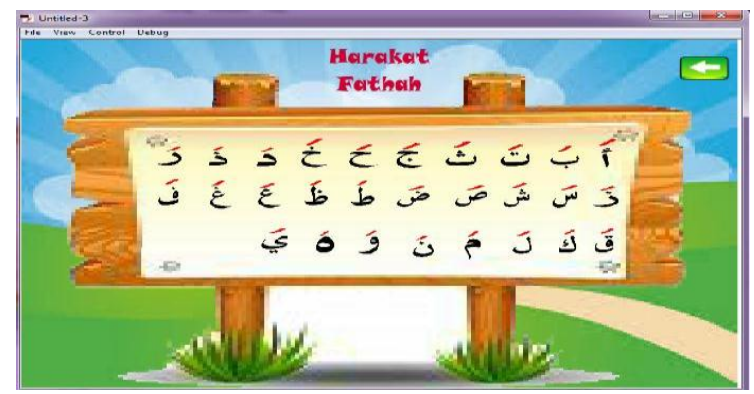

Picture 4. Material Page Fathah

\section{Halaman Materi Kasroh}

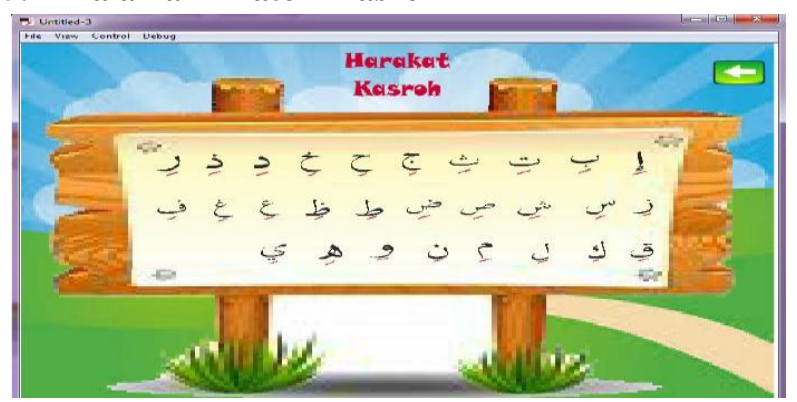

Picture 5. Material Page kasroh

\section{Halaman Materi Domah}

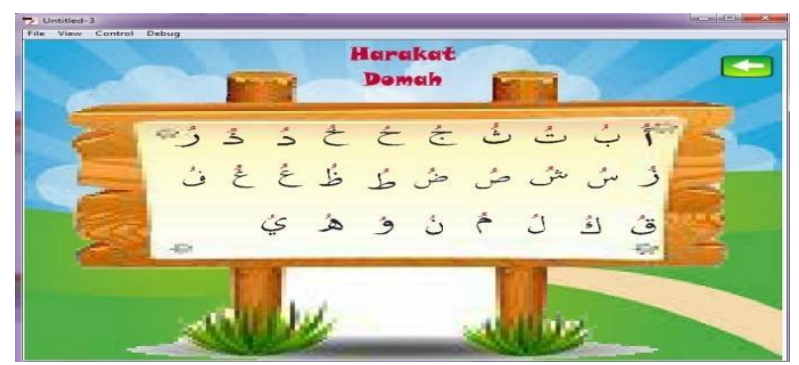

Picture 6.

Material Page Domah

\section{Game Page}

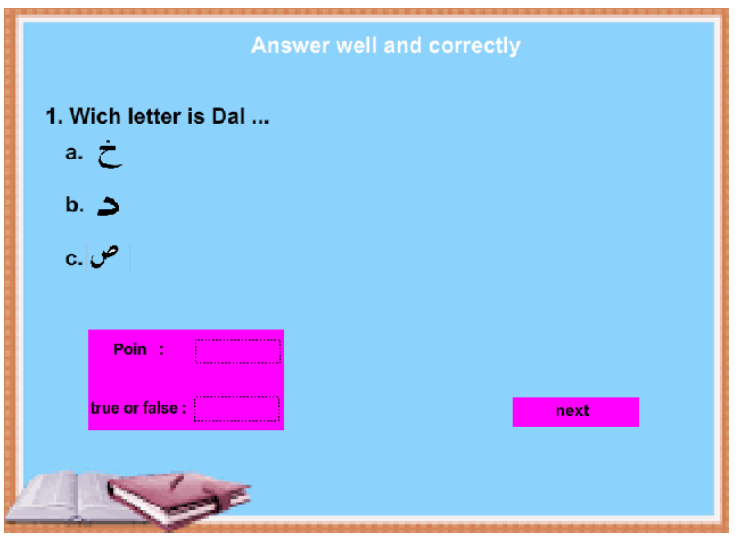

Picture 7. Game Page

8. Value Page

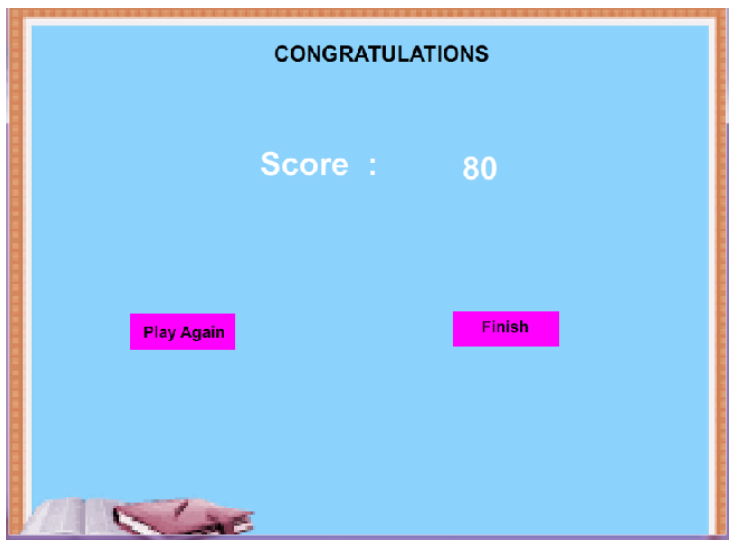

Picture 8. Value Page

D. Black Box Testing

In this test, it is done to ensure that an event or input will carry out the right process and produce output in accordance with the design made. 
Table 10

Black Box Testing Learning Menu Letters Hijaiyah

\begin{tabular}{|c|c|c|c|}
\hline $\begin{array}{c}\text { INPUT/EV } \\
\text { ENT }\end{array}$ & PROSES & $\begin{array}{r}\text { OUTPUT/NE } \\
\text { XT STAGE }\end{array}$ & $\begin{array}{c}\text { test } \\
\text { result }\end{array}$ \\
\hline \begin{tabular}{|c|} 
Button \\
\\
Introduction \\
Alphabet \\
Hijaiyah
\end{tabular} & $\begin{array}{c}\text { huruf.addEventList } \\
\text { ener(MouseEvent.C } \\
\text { LICK, ke_huruf); } \\
\text { function } \\
\text { ke_huruf(Event:Mo } \\
\text { useEvent):void\{ } \\
\text { gotoAnd } \\
\text { Stop("4"); } \\
\text { \} }\end{array}$ & \begin{tabular}{|c} 
Displaying \\
page \\
Letter material \\
Hijaiyah
\end{tabular} & $\begin{array}{c}\text { Correspo } \\
\text { nding }\end{array}$ \\
\hline $\begin{array}{c}\text { Button } \\
\text { Introduction } \\
\text { Harakat }\end{array}$ & $\begin{array}{c}\text { harokat.addEventLi } \\
\text { stener(MouseEvent. } \\
\text { CLICK, } \\
\text { ke_harokat); } \\
\text { function } \\
\text { ke_harokat(Event: } \\
\text { MouseEvent):void \{ } \\
\text { gotoAnd } \\
\text { Stop("harokat"); } \\
\text { \} }\end{array}$ & $\begin{array}{c}\text { Displaying } \\
\text { introduction } \\
\text { Harakat }\end{array}$ & $\begin{array}{c}\text { Correspo } \\
\text { nding }\end{array}$ \\
\hline $\begin{array}{l}\text { Button } \\
\text { Play }\end{array}$ & $\begin{array}{c} \\
\text { bermain.addEventL } \\
\text { istener(MouseEvent } \\
\text {.CLICK, } \\
\text { ke_bermain); } \\
\text { function } \\
\text { ke_bermain(Event: } \\
\text { MouseEvent):void }\{ \\
\text { gotoAnd } \\
\text { Stop(10); } \\
\}\end{array}$ & $\begin{array}{c}\text { Displaying } \\
\text { material } \\
\text { question } \\
\text { Alphabet } \\
\text { Hijaiyah }\end{array}$ & \begin{tabular}{|c} 
\\
Correspon \\
ding
\end{tabular} \\
\hline
\end{tabular}

according to [7] In making interactive animations learning to recognize letters and numbers, the author conducted several demonstrations to all students of Al-Hidayah Kindergarten Bekasi. After this animation was demonstrated, the writer tried to give a questionnaire in the form of a written question about how they thought about this animation after this animation was run. Since there are not many students in the classroom, the authors only give to 10 students consisting of 10 questions about animation learning to recognize letters and numbers.

\section{CONCLUSIONS AND SUGGESTIONS}

Based on the results of the research as well as the discussion that has been described, it can be withdrawn some conclusions as follows:

With the application of interactive animation introduction to hijaiyah letters for early childhood at Al-Hidayah Kindergarten Bekasi is very helpful in the teaching and learning process and yet becomes more fun and effective so students are no longer bored in learning and attract students to better understand on how to read the hijaiyah letters correctly. As well as helping teachers to innovate in the learning process because with this interactive animation application, the instructors become easier to deliver material about the prayer movements to students.

From the results of the research above, it is given suggestions that can be useful for development

1. In the menus of hijaiyah letters introduction animation, there are still quite a lot of flaws. Among them is the lack of motion animation that allows users to be interested in using this hijaiyah letter recognition animation. To overcome this problem, the writers give a suggestion for further development by adding a lot of motion animations to each scene in this animation so that users will certainly be interested in trying this animation.

2. In the menus of hijaiyah letters introduction animation, there are still quite a lot of flaws. Among them is the lack of motion animation that allows users to be interested in using this hijaiyah letter recognition animation. To overcome this problem, the writer gives a suggestion for further development by adding lots of motion animations to each scene so that users will be interested in trying this animation.

3. The authors realize that there are not only deficiencies that exist in the animation that the authors made, but in the report there are still enough deficiencies. Once again the author suggests that if there are other writers who want to develop this animation, it is hoped that it will be adjusted to the functions and desires of the majority of users, so that something produced can be useful effectively and efficiently for users.

\section{Bibliography}

[1] Susila, Candra Budi dan Erlina Idola Ganis. 2012 Media Pembelajaran Interaktif Pengenalan Huruf Hijaiyah Pada TK Pertiwi Kecamatan Pacitan, seruni FTI UNSA. Vol 1,2012

[2] Husaini, F. (2012, February). Pembuatan Media Edukasi Ayo Bermain Huruf Hijaiyah Pada TPA 
An-Nur Daleman. In Seruni-Seminar Riset Unggulan Nasional Informatika (Vol. 1, No. 1).

[3] Ida rosmidah, Henny Destiana. 2017 Perancangan Animasi Interaktif Belajar Mengenal Huruf Hijaiyah Pada TKQ Al-Khoiriyah. Jurnal Teknik Komputer AMIK BSI. Vol III, No 1, Februari 2017.

[4] A.S. Rosa dan Shalahuddin, M. 2015. Rekayasa Perangkat Lunak. Bandung: Informatika.

[5] Chandra.(2011). 7 Jam Blajar Interaktif Flash CS5 Untuk Orang Awam. Palembang:Maxikom

[6] Anggara,Raditya. 2012. Jalan Pintas Mahir Photoshop Setingkat Grand Master. Yogyakarta: Citra Media

[7] Bakri, A., Zakaria, N. H., Zainuldin, S. N. M., \& AbuSafia, A. H. (2014, September). A conceptual model of Al-Furqan courseware using persuasive system design for early learning childhood. In 2014 8th. Malaysian Software Engineering Conference (MySEC) (pp. 336341). IEEE. 